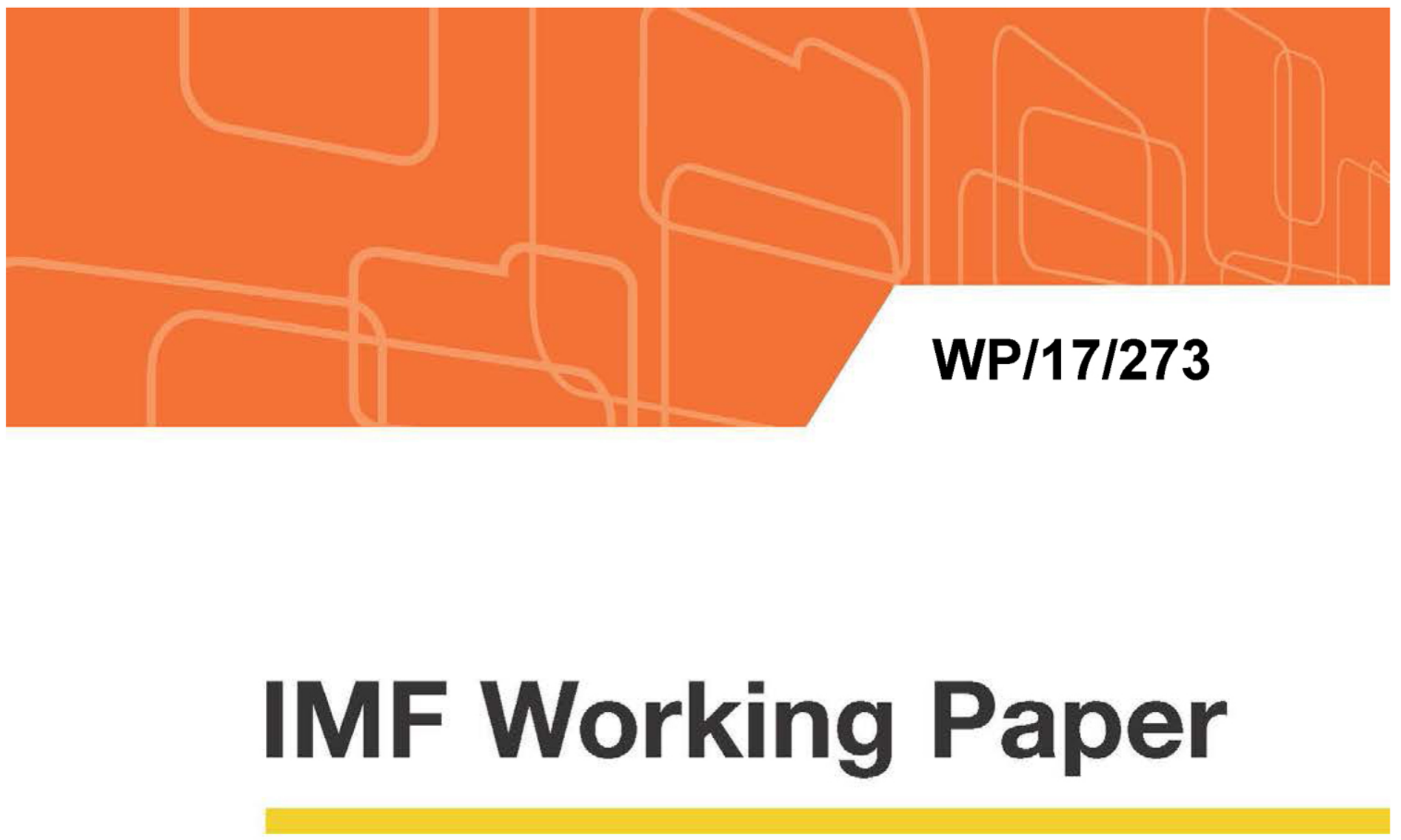

\title{
Credit and Fiscal Multipliers in China
}

by Sophia Chen, Lev Ratnovski, and Pi-Han Tsai

IMF Working Papers describe research in progress by the author(s) and are published to elicit comments and to encourage debate. The views expressed in IMF Working Papers are those of the author(s) and do not necessarily represent the views of the IMF, its Executive Board, or IMF management. 


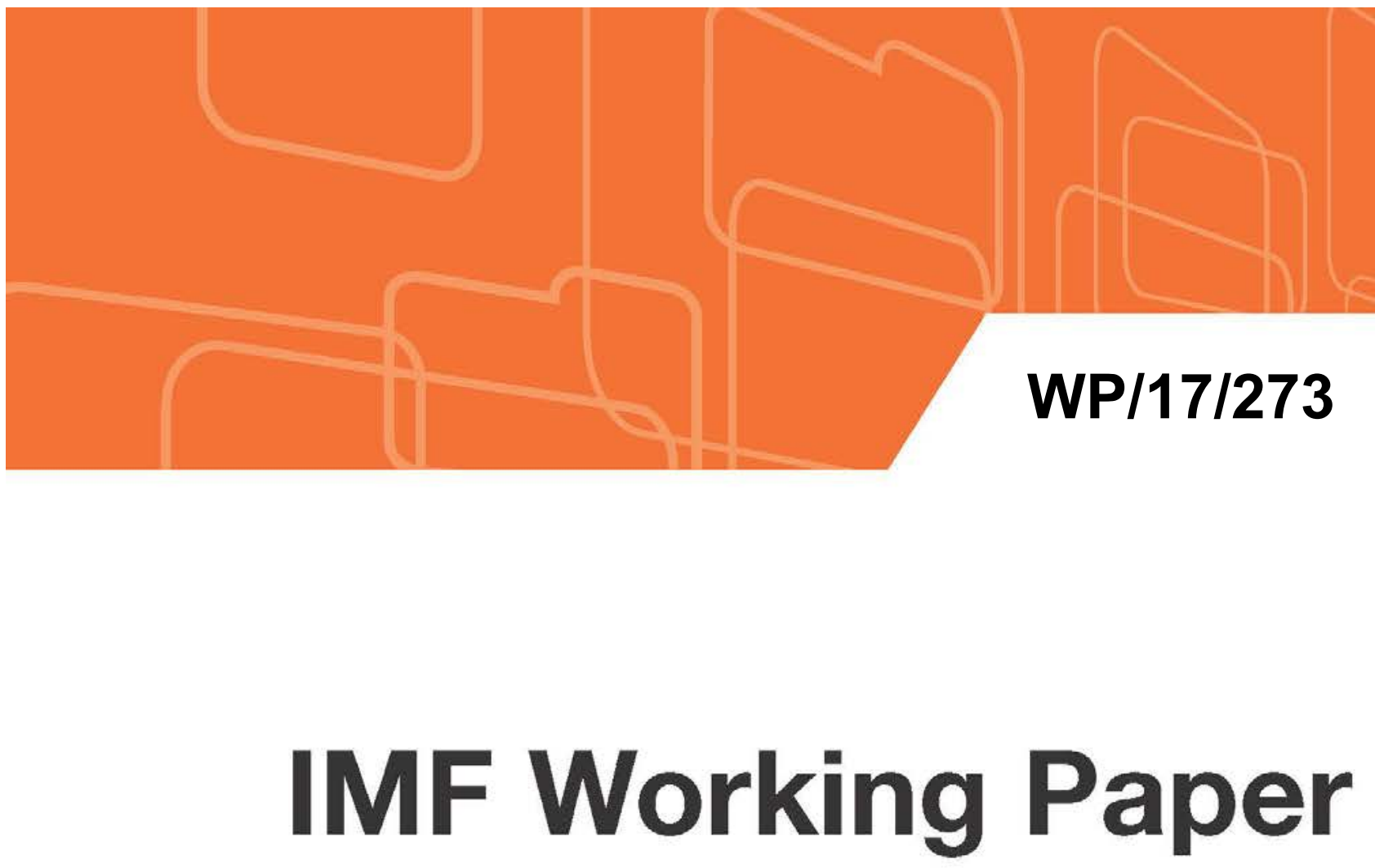

\section{Credit and Fiscal Multipliers in China}

by Sophia Chen, Lev Ratnovski, and Pi-Han Tsai

IMF Working Papers describe research in progress by the author(s) and are published to elicit comments and to encourage debate. The views expressed in IMF Working Papers are those of the author(s) and do not necessarily represent the views of the IMF, its Executive Board, or IMF management.

$$
\text { I N T E R N A T I O N A L M O N E T A R Y F E N D }
$$




\title{
IMF Working Paper
}

Research Department

\section{Credit and Fiscal Multipliers in China}

\section{Prepared by Sophia Chen, Lev Ratnovski, and Pi-Han Tsai ${ }^{1}$}

\author{
Authorized for distribution by Maria Soledad Martinez Peria
}

December 2017

\begin{abstract}
IMF Working Papers describe research in progress by the author(s) and are published to elicit comments and to encourage debate. The views expressed in IMF Working Papers are those of the author(s) and do not necessarily represent the views of the IMF, its Executive Board, or IMF management.
\end{abstract}

\begin{abstract}
We jointly estimate credit and fiscal multipliers in China. We use the tenure of the provincial party secretary, interacted with the type of stimulus used in other provinces, to obtain separate instruments for provincial credit and government expenditure. We estimate a fiscal multiplier of 0.8 and a credit multiplier of 0.2 in 2001-2015. The multipliers have changed over time. The fiscal multiplier has increased from 0.75 in 2001-2008 to 1.4 in 2010-2015. The credit multiplier has declined from 0.17 to zero over the same periods. Our results suggest that reducing credit growth in China is unlikely to disrupt output growth, whereas fiscal policy may be effective in supporting macroeconomic adjustment.
\end{abstract}

JEL Classification Numbers: E63, G21, H20, R12

Keywords: Credit Growth, Fiscal Stimulus, Macroprudential Policy, Multipliers, China Authors' E-Mail Addresses: ychen2@,imf.org; 1ratnovski@imf.org; pihant@zju.edu.cn.

\footnotetext{
${ }^{1}$ We thank James Daniel, Giovanni Dell'Ariccia, Joong Shik Kang, Divya Kirti, Petya Koeva Brooks, and Maria Soledad Martinez Peria for useful comments, and Hala Moussawi and Huy Nguyen for excellent research assistance.
} 


\section{Contents}

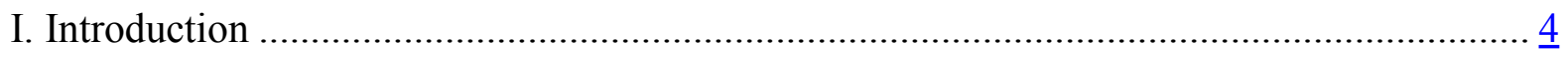

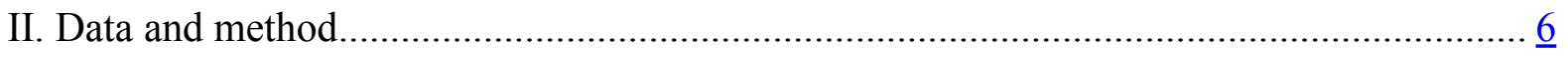

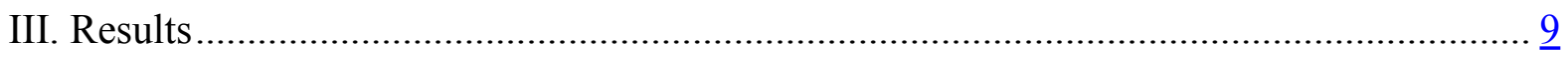

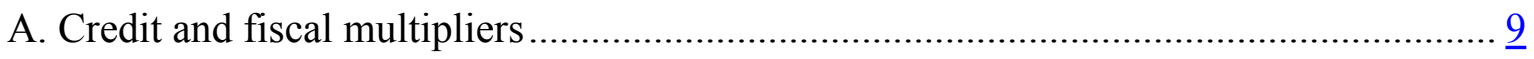

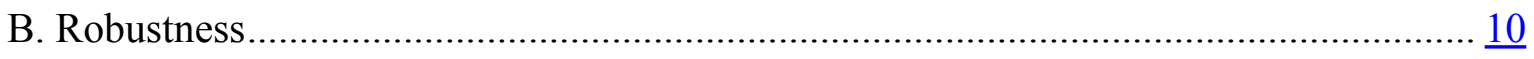

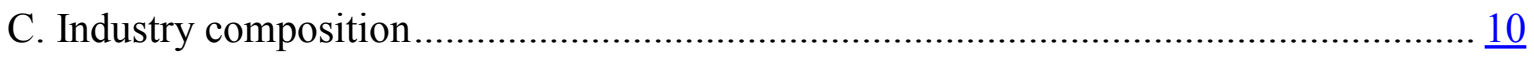

D. Discussion on "open economy multipliers"............................................................

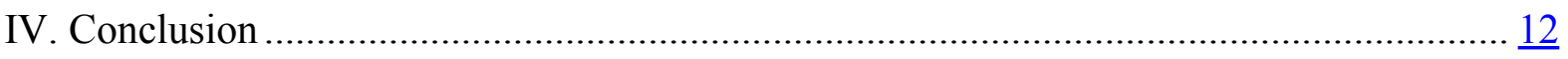

Figure 1. The correlation of bank loans and TSF growth................................................. 13

Figure 2. Appointments of provincial party secretaries..................................................... 14

Figure 3. Credit and expenditure growth over the tenure of provincial party secretaries …... 15

Figure 4. Sensitivity to other provinces' stimulus policies over the tenure of provincial

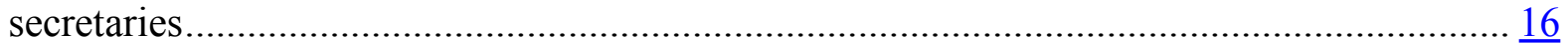

Table 1. Summary statistics ................................................................................... 17

Table 2. Appointments of party secretaries and provincial economic conditions ................... 18

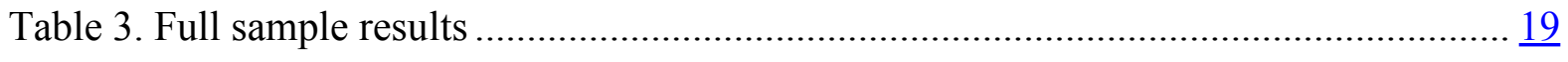

Table 4. Early and late subsamples results .................................................................. 20

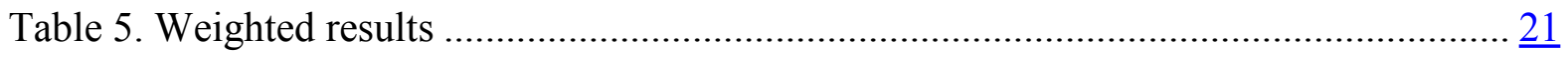

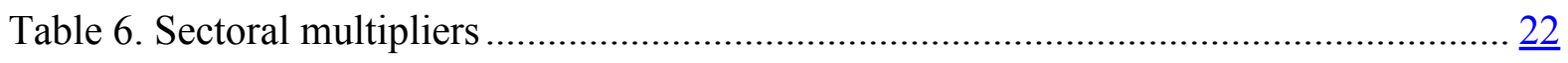

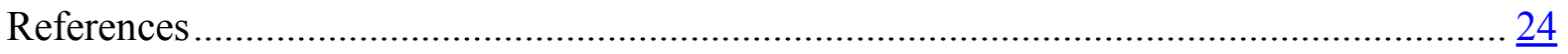




\section{INTRODUCTION}

The Chinese economy has been growing at 13.5 percent on average since 2001 . The growth has slowed somewhat in the post-Global Financial Crisis (GFC) period. In response, the Chinese authorities adopted a set of accommodative macroeconomic policies, including a major credit expansion. Total social financing (TSF, a wide measure of credit) has more than doubled since 2001, reaching about 200 percent of GDP in 2016. Bank credit and nonfinancial corporate debt have reached 145 percent of GDP.

The rapid pace of credit expansion in China raises challenges. On the one hand, it creates credit boom-related risks of financial instability, even though the authorities may have sufficient policy tools to deal with possible disruptions (IMF, 2017). On the other hand, a reduction in credit growth may impose a drag on economic activity. To the extent that the Chinese authorities are committed to growth targets, and against the broader backdrop of a slowdown in global trade and productivity growth, stimulus will need to be provided by other means, presumably, fiscal. This paper aims to provide a rigorous joint estimation of credit and fiscal multipliers in China, to help assess the macroeconomic implications of such a rebalancing.

The estimation of multipliers is empirically challenging, because macroeconomic policies are rarely exogenous to macroeconomic conditions. Fiscal expenditure may increase during economic upturns because of looser budget constraints, or in the downturns due to countercyclical fiscal policy. Credit is also endogenous because credit demand is procyclical (Bernanke and Gertler, 1995). Prior literature on fiscal multipliers has addressed the endogeneity problems with structural vector autoregressions (VAR). But the validity of VAR results hinges on the model's structural assumptions. Other papers have examined expenditure shocks that are plausibly unrelated to macroeconomic conditions, such as military spending (see Spilimbergo et al., 2009 for a review). Here, the challenge is to control for the changes in macroeconomic conditions that coincide with the exogenous shocks. Nakamura and Steinsson (2014) address this with an "open economy multiplier" setup that captures the effect of a relative change in spending in one region-compared to other regions in the same economic area-on its relative output, while controlling for aggregate macroeconomic shocks. We apply a similar approach to estimate the open economy multipliers for Chinese provinces.

While most of the literature on multipliers focuses on fiscal multipliers, we also employ the concept of a credit multiplier to assess the sensitivity of output to credit growth. A credit multiplier captures the effectiveness of credit growth in supporting real activity. Prior theory suggests that credit growth supports real activity through wealth effects and a financial accelerator mechanism (see, among others, Bernanke and Gertler, 1989; Kiyotaki and Moore, 1997; Gilchrist and Zakrajsek, 2012). Consistent with the theory, cross-country empirical studies find a positive relationship between credit growth and GDP growth, operating through private consumption and private investment (e.g. Dell'Ariccia et al., 2016).

It seems essential in the Chinese context to estimate credit and fiscal multipliers jointly. China actively uses credit growth as a policy tool, setting policy-driven targets for aggregate 
credit and its allocation (Tao, 2006; Li et al., 2008; Wong, 2011). To the extent that credit and fiscal stimuli can complement or substitute each other to achieve desired economic outcomes, it is important to understand their separate and joint effects both for policy purposes and for correct empirical identification.

To achieve identification, we use the tenure of provincial party secretaries as a source of exogenous variation in stimulus policies in Chinese provinces. ${ }^{2}$ This is based on two formally-tested observations. First, the timing of the appointments (and reappointments) of provincial party secretaries is unrelated to local economic conditions. Second, provincial party secretaries have incentives to use stimulus policies at strategically important times during their tenure to improve the prospect of their retention or promotion. The crossprovince variation in the tenure of provincial party secretaries, which drives their differential incentives for stimulus policies, allows us to identify the exogenous variation in stimulus policies.

A challenge we face compared to prior studies on multipliers is that we need not one, but two instruments to jointly estimate credit and fiscal multipliers. We address this by interacting the tenure of the provincial party secretary with credit and expenditure growth in all other provinces. We verify that, all else equal, a provincial stimulus is more likely to be provided through credit (fiscal) means when other provinces have higher credit (expenditure) growth.

To achieve identification, the instruments should only affect the dependent variable (provincial growth) through the explanatory variables (stimulus policies), and not directly. Here one might have two potential concerns about using the policy mix in other provinces as part of the instrument. First, it is possible that stimulus in other provinces is associated with aggregate macroeconomic conditions. In our specification, this channel is absorbed by year fixed effects. Second, it might be that stimulus in other provinces may affect a province's growth relative to other provinces, for instance, by boosting demand in other provinces. To the extent that this effect is present, stimulus in other provinces would have a negative effect on provincial relative output growth, implying that our estimates would be biased downwards from the true multipliers. ${ }^{3}$

Our instrumental variables (IV) estimate yields a fiscal multiplier of 0.8 and a credit multiplier of 0.2 over 2001-2015. The fiscal and credit multipliers estimated jointly are lower than those estimated separately, suggesting that provinces use fiscal and credit stimuli as complements. We also find that the fiscal multiplier has increased from 0.75 in 2001-2008 to 1.4 in 2010-2015. Over the same periods, the credit multiplier has declined from 0.17 to zero. These results suggest that, at present, reducing credit growth in China is unlikely to disrupt output growth, whereas fiscal policy may be effective in supporting macroeconomic adjustment.

\footnotetext{
${ }^{2}$ The provincial party secretary is the de facto person in charge of the province (Li and Zhou, 2005). In alternative specifications (not reported), we substituted province secretary's tenure with province governor's tenure. Our main conclusions are not affected although the effects are in general smaller.

${ }^{3}$ Such spillover-related biases would be present in any "open economy multiplier" models.
} 
Our estimate of the pre-GFC fiscal multiplier in China is consistent with He et al. (2009), whose estimate is in the range of 0.84-1.1. The finding that the fiscal multiplier has increased as output growth has slowed is consistent with the broader literature on the relationship between fiscal multipliers and the state of the economy (Auerbach and Gorodnichenko, 2012; Baum et al., 2012; Blanchard and Leigh, 2013). A decline in the credit multiplier may be driven by the over-saturation of the economy with credit, and resulting credit misallocations (Song et al., 2011; Cong et al., 2017; Ru, 2017).

In an extension, we study the effects of credit and fiscal stimuli on industry composition. We find that both credit and fiscal stimuli boost construction and manufacturing, but not services. The result that credit boosts external finance-dependent sectors is unsurprising. The result that fiscal stimulus has a similar industrial bias is less mechanical, but consistent with the observation that fiscal stimulus has been targeted at infrastructure and related industries (Wong, 2011). ${ }^{4}$ Thus, for the fiscal stimulus to support the rebalancing of the economy towards services, it should also be rebalanced, for example towards social expenditure.

In interpreting our results, it is useful to note that our fiscal multiplier is an on-balance-sheet expenditure multiplier. Part of sub-national expenditures in China-including those through local government funding vehicles (LGFV) - is off-balance-sheet and financed with bank loans (IMF, 2017). As a result, the off-balance-sheet multiplier is likely lower than the onbalance-sheet multiplier.

The rest of the paper proceeds as follows. Section II discusses our data and method. Section III presents the results. Section IV concludes.

\section{DATA AND METHOD}

We use data from 31 provincial units of China: 4 centrally administrated cities (Beijing, Shanghai, Tianjing, and Chongqing), 22 provinces, and 5 autonomous regions (Guangxi, Inner Mongolia, Ningxia, Tibet, and Xinjiang). The main data source is CEIC China Premium Database. ${ }^{5}$ Our sample period is 2001-2015. Table 1 shows data summary statistics.

We measure provincial fiscal stance by total expenditure, and provincial credit as the sum of bank loans in domestic and foreign currencies granted in the province. The main variable of interest is provincial GDP. We deflate all variables to $2010 \mathrm{RMB}$ using national CPI. For provincial political cycle, we manually collect data on provincial party secretaries from the

\footnotetext{
${ }^{4}$ For example, in the 2008-2009 fiscal stimulus in China, transportation and power infrastructure accounted for the highest share of expenditure (37.5\%) and health and education for the lowest (3.8\%), according to the National Development and Reform Commission. Prior literature suggests that local policymakers prefer to spend on infrastructure because that leads to more easily quantifiable outputs (O'Brien and Li, 1999; Jin et al., 2005; Luo et al., 2010).

${ }^{5}$ https://www.ceicdata.com/en
}

(continued...) 
Chinese politics and vitae websites. The data record the names of all provincial party secretaries, their appointment terms, and personal profiles. ${ }^{6}$

The use of bank loans as a measure of credit in China deserves some discussion. Bank loans reflect only a subset of overall credit which also includes bonds, credit from non-banks (e.g. wealth management products), and other instruments. At the aggregate level, overall credit in China is measured by "total social financing" (TSF). However, data on province-level TSF is limited. In the aggregate, the bank loans and TSF growth rates (as a share of GDP) have a high correlation of 0.93 (or 0.84 if the 2009 outlier year is excluded, see Figure 1), suggesting that bank loans growth is a good proxy for overall credit growth.

Our analysis is at the province level instead of a more geographically granular county level. There are several reasons. First, provinces have more control over local macroeconomic policies than counties do (Wedeman, 1999; Shen et al., 2012). Second, the credit multiplier estimation relies on the assumption that credit granted in a province gets spent there. This assumption would have been more problematic on a geographically granular county level.

Our empirical specification follows Nakamura and Steinsson (2014) and is extended to include both government expenditure and credit. Specifically, we estimate the equation:

$$
\frac{Y_{i t}-Y_{i t-2}}{Y_{i t-2}}=\alpha_{i}+\gamma_{t}+\beta_{G} \frac{G_{i t}-G_{i t-2}}{Y_{i t-2}}+\beta_{C R} \frac{C R_{i t}-C R_{i t-2}}{Y_{i t-2}}+\varepsilon_{i t},
$$

where $Y_{i t}$ is GDP, $G_{i t}$ is government expenditure, $C R_{i t}$ is credit, all in province $i$ in year $t$. We include province and year fixed effects $\alpha_{i}$ and $\gamma_{t}$. Province fixed effects capture time-invariant differences in output growth and other heterogeneity across provinces. Year fixed effects control for the aggregate macroeconomic conditions and centralized fiscal, monetary, and exchange rate policies. As in Nakamura and Steinsson (2014), we use two-year changes to capture the dynamics of multipliers. Hence, our model allows for a sluggish response of output to expenditure and credit. ${ }^{7}$ To account for the overlapping nature of observations, we cluster standard errors $\varepsilon_{i t}$ at the province level. Shocks to government expenditure and credit are normalized by the initial provincial GDP, so the stimulus is expressed in as percentage points of initial GDP. The coefficients $\beta_{G}$ and $\beta_{C R}$ capture the fiscal and credit multipliers.

The main challenge in identifying the effect of government expenditure and credit on GDP is that the explanatory variables are likely endogenous. For this reason, we estimate equation

\footnotetext{
${ }^{6}$ Source for appointment terms: www.zt360.cn (Zheng Tan Wang). Sources on personal profiles: http://ldzl.people.com.cn (Ren Min Wang) and http://news.xinhuanet.com (Xin Hua Wang). Personal profiles include age, gender, education, central connection (i.e. membership or alternate membership of the party central committee), and localness (i.e. whether the secretary was born or promoted in the same province as the current position). In alternative specifications not reported, we include personal profile indicators in the first-stage regression and find that most are not statistically significant. The only significant indicator is membership of the party central committee, but including this indicator does not change our second-stage results. We therefore opt for a more parsimonious specification.

${ }^{7}$ An alternative specification based on one-year changes in the variables, but with contemporaneous and oneyear lagged regressors (not reported), produces similar results.
} 
(1) using an instrumental variables approach. We base the instrumentation on the literature on sub-national political cycles in China, and use the tenure of provincial party secretaries as a source of exogenous variation in stimulus policies. This is based on two observations.

First, prior literature suggests that the appointments of provincial party secretaries follow a pattern that is exogenous to provincial economic conditions. Most appointments occur at the end of the 5-year term of the previous secretary, or after the national party congress ( $\mathrm{Li}$ and Zhou, 2005; Tsai, 2016; see Figure 2). To formally verify that the appointments are not associated with local economic conditions, we estimate a probit model of party secretary appointments, where the independent variable is an indicator variable that takes the value of one if a new secretary is appointed. The results, shown in Table 2, confirm that the probability of an appointment is not associated with contemporaneous, or 1- or 2-year lagged GDP growth, per capita GDP growth, or employment growth. ${ }^{8}$

Second, leaders have incentives to use macroeconomic stimulus at strategically important times during their tenure to improve the prospect of their retention or promotion. Figure 3 shows that provincial credit and expenditure growth peak towards the end of the first fiveyear term of the secretary, and then peak again in the middle of the second five-year term. Further to the cyclicality, the incentives to engage in provincial economic stimulus policies increase over the tenure of the provincial party secretary. ${ }^{9}$

Moreover, when choosing the modality of the stimulus, a province is more likely to use credit stimulus when other provinces have higher credit growth, and fiscal stimulus when other provinces have higher expenditure growth. Figure 4 panel A shows that provincial credit growth is associated with credit growth in other provinces, but not with expenditure growth in other provinces (all controlling for province and year fixed effects). Also, interestingly, the sensitivity of provincial credit growth to credit growth in other provinces increases with the tenure of the provincial party secretary, perhaps because of the increasing magnitude of the stimulus. Figure 4 panel B shows similar patterns for the sensitivity of expenditure growth. ${ }^{10}$

\footnotetext{
${ }^{8}$ Consistent with model (1), the probit uses two-year growth and includes province and year fixed effects. The results without fixed effects are similar. Also, the results are robust to controlling for reappointments. Note that the finding that the appointments are unrelated to provincial economic conditions does not contradict performance-based evaluation of provincial party secretaries. First, if the incumbent secretaries are equally likely to be promoted for good performance or terminated for bad performance, the relationship between economic conditions and secretary appointments remains ambiguous. Second, even if a leader is likely to be promoted or terminated, the exact timing of that may still be determined by factors such as secretary's tenure or the reshuffling of personnel at the national level. Further, Li and Zhou (2005) show that secretary promotions or terminations are more related to average multi-year rather than short-term performance.

${ }^{9}$ The decrease in credit growth in years 8-9 of the tenure has little statistical importance, because the frequency of tenure over 7 years is very low ( 3 percent in our sample). The finding on the cyclicality of provincial stimulus is consistent with Guo (2009) who shows that county expenditure growth peaks in the third and fourth year of a county leader's tenure.

${ }^{10}$ Again, the high sensitivity of provincial expenditure growth to other provinces' credit growth in years 8-9 has little statistical importance, because of a low frequency of tenures longer than 7 years.
}

(continued...) 
Our identification uses these political cycle patterns as a source of exogenous variation in stimulus policies. The "first stage" of our two-stage least squares (2SLS) procedure regresses provincial credit and government expenditure growth on those in other provinces, interacted with the tenure of the provincial party secretary, after controlling for year and province fixed effects. This yields fitted values of credit and expenditure growth for each province, which we use in the second stage regression. ${ }^{11}$

\section{RESUlts}

\section{A. Credit and fiscal multipliers}

Our results on credit and fiscal multipliers in China over the entire 2001-15 period are shown in Table 3. We report the credit multiplier estimated separately (columns 1-2), the fiscal multiplier estimated separately (columns 3-4), and credit and fiscal multipliers estimated jointly (columns 5-6). In each case, we report ordinary-least-squares (OLS) estimates first, followed by IV estimates. The multipliers capture the percentage change in GDP in response to a change in credit or in government expenditure by one percentage point of initial GDP.

Column 6 shows our headline result — a credit multiplier of 0.2 , and a fiscal multiplier of 0.8 - jointly estimated in an IV specification.

It is useful to compare the results obtained in various specifications. The point estimates of credit and fiscal multipliers estimated separately (columns 2 and 4) are higher than those estimated jointly (column 6). This suggests that the authorities tend to use credit and fiscal stimuli simultaneously. Consequently, a separate estimation of credit or fiscal multipliers has an upwards bias, as it omits the effect of additional contemporaneous stimulus through alternative (fiscal or credit, respectively) means. The point estimates of credit and fiscal multipliers in the OLS estimation (columns 1,3, and 5) are somewhat lower than those in the IV estimation (columns 2, 4, and 6). This reflects the countercyclicality of fiscal and credit policy: expenditure and credit growth are high when GDP growth is low. Countercyclical policies lead to a downward bias in the OLS estimates, compared to the IV estimates that correct for this endogeneity. Interestingly, the wedge in OLS and IV estimates is higher for the credit multiplier than for the fiscal multiplier, possibly because budget constraints limit the amount of fiscal stimulus in recessions but less so for credit stimulus.

A central question in the policy debate on the effects of credit growth in China is whether the credit multiplier might have declined as the economy became more saturated with credit. Table 4 aims to shed light on the evolution of the multipliers in China by estimating them

\footnotetext{
${ }^{11}$ We report results for weak instrument test for all our IV specifications. As Table 3 shows, the Cragg-Donald Wald F-test for excluded instruments comfortably exceeds the critical values tabulated by Stock and Yogo (2005).
}

(continued...) 
separately over two periods: 2001-2008 and 2010-2015. We interpret these as "normal times" multipliers because they exclude the GFC period. ${ }^{12}$

We find that the credit multiplier in China has substantially declined in recent years, and is now close to zero. The credit multiplier was 0.17 in 2001-2008 (column 2), but is statistically insignificant in 2010-2015 (column 4). The decline in the credit multiplier is consistent with previous findings that credit boom leads to credit misallocations and inefficiency. In contrast, the fiscal multiplier has increased from 0.75 in 2001-2008 to 1.4 in 2010-2015. The finding that the fiscal multiplier has increased as output growth slowed is consistent with the broader literature on the relationship between fiscal multipliers and the state of the economy. ${ }^{13}$

Overall, our results suggest that, at present, a reduction in credit growth is unlikely to disrupt output growth. At the same time, fiscal policy may be effective in supporting growth targets. One caveat is that an abrupt reversal in credit growth may affect financial stability. This type of nonlinear response is not captured by our analysis.

\section{B. Robustness}

As a robustness check, we replicate our regressions in a specification that weights observations by provincial GDP. The weighted results give prominence to larger provinces. Table 5 reports the results. The weighted results for the credit multiplier are similar to the unweighted results, including the zero credit multiplier in the 2010-2015 period. The weighted results for the fiscal multiplier are somewhat larger than the unweighted results, suggesting that fiscal stimulus may be more effective in more developed provinces.

\section{Industry composition}

There is a broadly held opinion that the Chinese economy can achieve a more sustainable growth path through a rebalancing from the manufacturing and construction sectors towards services. To shed light on how credit and fiscal policies may contribute to the rebalancing, we examine the effects of credit and fiscal stimuli on industry composition. We estimate the following regression:

$$
\frac{\operatorname{Ind}_{i j t}-\operatorname{Ind}_{i j t-2}}{Y_{i t-2}}=\alpha_{i}+\gamma_{t}+\beta_{G} \frac{G_{i t}-G_{i t-2}}{Y_{i t-2}}+\beta_{C R} \frac{C R_{i t}-C R_{i t-2}}{Y_{i t-2}}+\varepsilon_{i t},
$$

where Ind $d_{i j t}$ is the output of industry $j$ in province $i$ in year $t$. The coefficients $\beta_{G}$ and $\beta_{C R}$ capture the increase in industry output (in percentage points of GDP) in response to an increase in credit or in government expenditure by one percentage point of GDP. This specification effectively disaggregates the overall output multiplier by sector. Because

\footnotetext{
${ }^{12}$ Since the subsample estimates omit the GFC period (the observations based on 2007-09, 2008-10, and 200911 growth rates), the subsample estimates need not average up to the estimates for the full sample. During the GFC period, the credit multiplier appeared high, while the credit multiplier appeared low. Formal estimations during the GFC period are imprecise because of the short sample.

${ }^{13}$ The one-sided Z-scores for the difference between early and late sample IV estimates are 1.458 for credit and 1.682 for expenditure, which are significant at the 10 percent and 5 percent respectively.
} 
sectoral output sums up to aggregate output, the effects on all sectors also sum up to the aggregate multiplier. For this reason, we refer to $\beta_{G}$ and $\beta_{C R}$ as sectoral contributions to the aggregate multipliers ("sectoral multipliers").

The results for sectoral multipliers are shown in Table 6. Panel A reports the results for the entire sample. Panel B reports the results for the 2010-2015 period. We report the results for construction (columns 1-2), manufacturing (columns 3-4), and services excluding financials (columns 5-6). As before, we report the OLS estimates first, followed by IV estimates.

The effect of fiscal and credit stimulus on industry growth can be inferred by dividing $\beta_{G}$ and $\beta_{C R}$ by the share of the sector in GDP. This calculation is shown in Panel C. The results show that fiscal and credit stimuli have the largest effect on manufacturing and, somewhat less so, on construction. This is consistent with the observation that fiscal stimulus often targets manufacturing. The stimuli have the smallest effect on the services sector. Moreover, over 2010-2015, credit stimulus might have served to constrain the growth of the services sector (column 6). ${ }^{14}$ This might be related to a reallocation of resources from services to manufacturing (as in, e.g., Borio et al., 2016). Overall, the results suggest that, in order to contribute to the rebalancing of the economy towards services, the new fiscal stimulus should be designed to target services more than the historical fiscal stimulus did.

\section{Discussion on "open economy multipliers"}

We estimate credit and fiscal multipliers with provincial data using an "open economy multiplier" approach that captures the effect of a relative change in the macroeconomic stance in one region on its relative output, while controlling for aggregate macroeconomic shocks (Nakamura and Steinsson, 2014). To what extent are these estimates representative of aggregate multipliers?

First, provincial and central governments may have different expenditure structure, which may affect the effectiveness of stimuli and hence the magnitude of the multipliers. In China, the central government is responsible for national defense, foreign affairs, geological prospecting, and national debt; whereas the sub-national governments are responsible for urban maintenance and construction, environment, water supply, and community services. In principle, all other responsibilities - including education, health care, social welfare, public safety, and local economic development - are shared by the central and sub-national governments. But in practice, most of spending in the shared categories is done by subnational governments (Shen et al, 2012). Based on this central-provincial distribution of responsibilities, it appears that most of the traditional targets of discretionary stimulus policies (e.g. infrastructure, urban development, and social spending) are effectively at the

\footnotetext{
14 The instruments are somewhat weak for the service sector in the post-crisis period (Cragg-Donald Wald F statistic is 11.99, compared to the Stock and Yogo (2005) 5 percent IV relative size value of 13.97), suggesting that the IV estimate may be somewhat biased towards OLS estimates (Bound, Jaeger, and Baker 1995).
}

(continued...) 
provincial responsibility level. Therefore, one might expect the province-level fiscal multipliers to be well representative of the aggregate fiscal multipliers. ${ }^{15}$

Second, the "open economy multipliers" do not account for the endogenous macroeconomic response to aggregate stimulus (such responses are absorbed in year fixed effects). For example, aggregate credit or fiscal stimulus may induce a monetary policy reaction: a monetary contraction in response to a positive stimulus or a monetary accommodation in response to a negative stimulus. These endogenous effects would imply that the aggregate multipliers may be smaller than our estimates.

Finally, we identify our multipliers based on the stimulus stance in other provinces. This identification may be affected by nonlinearities. For example, the effectiveness of additional stimulus might be lower when other provinces are also engaging in stimulus. This would imply that the magnitude of aggregate multipliers may be larger than our estimates. We also cannot rule out that the multipliers might be different were underlying output growth rates to substantially diverge from historic averages (e.g. in the case of an economic slowdown).

\section{CONCLUSION}

We use a novel instrumentation strategy to jointly estimate credit and fiscal multipliers in China. Our instruments are based on provincial political cycles interacted with credit and expenditure growth in other provinces. We use the former to capture exogenous variations in a provincial leader's incentives to adopt stimulus policies; and the latter to capture the credit versus fiscal stimulus mix.

Our results shed light on the policy debates on the real implications of credit expansion and on growth rebalancing in China. We estimate a fiscal multiplier of 0.8 and a credit multiplier of 0.2 over 2001-2015. Furthermore, we find that the credit multiplier in China has recently been effectively zero. In contrast, the fiscal multiplier has recently increased to 1.4. This implies that slower credit growth is unlikely to disrupt output growth, while fiscal policy may be effective in supporting macroeconomic adjustment. We further found that fiscal stimulus in China primarily boosts manufacturing. Consequently, future fiscal stimulus would need to be rebalanced towards services-related expenditure (health, education, etc.) to contribute to the rebalancing of the Chinese economy towards services.

\footnotetext{
${ }^{15}$ At the sub-national level, higher-level government has discretion on the expenditure responsibilities of the government in a level immediately below it. In other words, the provincial government has influence on all sub provincial-level expenditure (including cities, prefectures, counties, townships) (Shen et al, 2012)
} 
Figure 1. The correlation of bank loans and TSF growth.

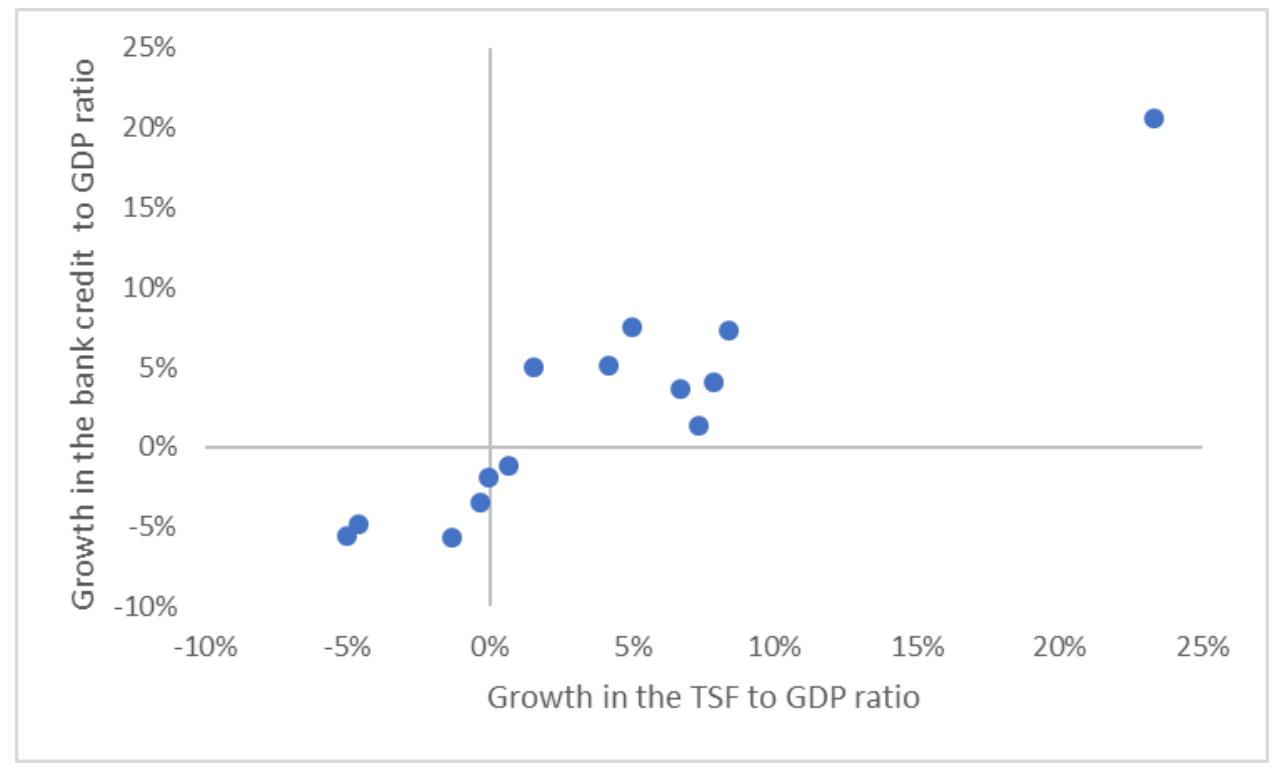

Note: This figure plots annual growth of aggreaget total social finacing (TSF) and bank credit as a share of GDP.

Source: CEIC and authors' calculation. 
Figure 2. Appointments of provincial party secretaries

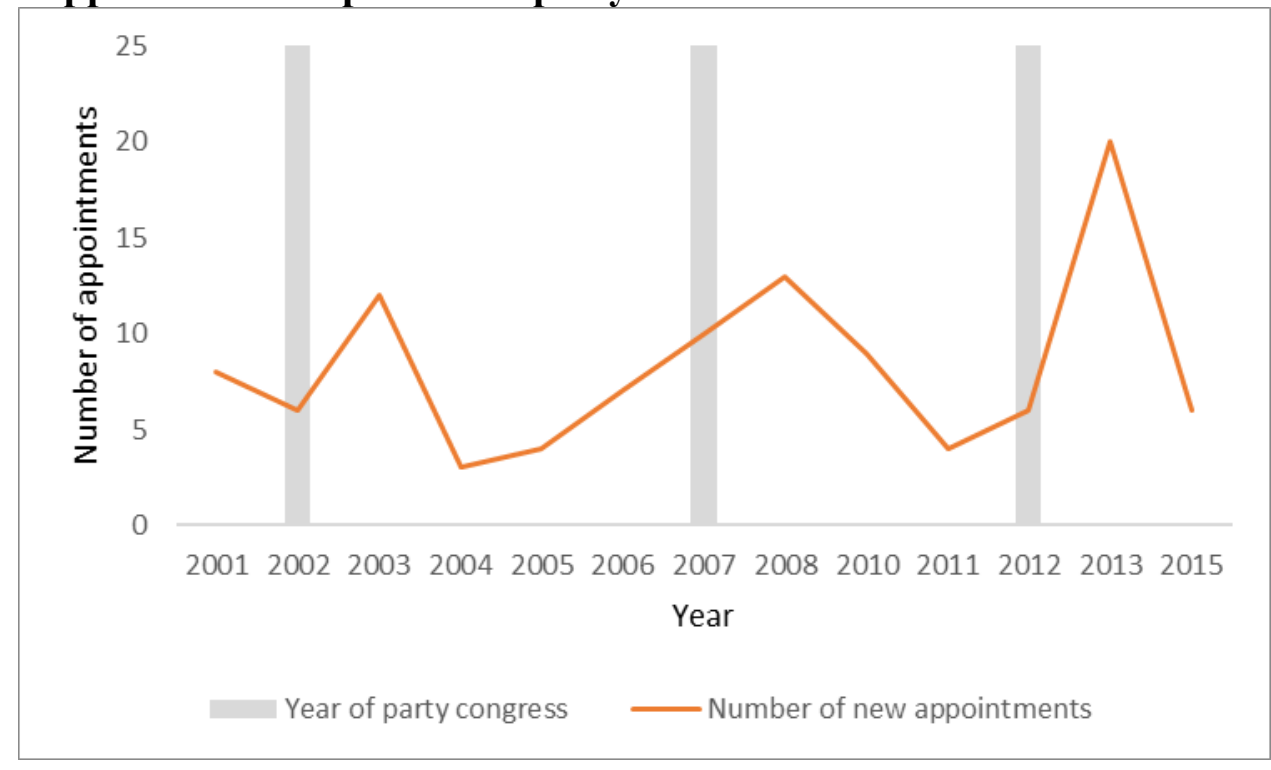

Note: This figure plots the number of newly appointed provincial party secretaries by year. Grey areas are the years of the national party congress.

Source: Zheng Tan Wang (www.zt360.cn) and authors' calculation. 
Figure 3. Credit and expenditure growth over the tenure of provincial party secretaries

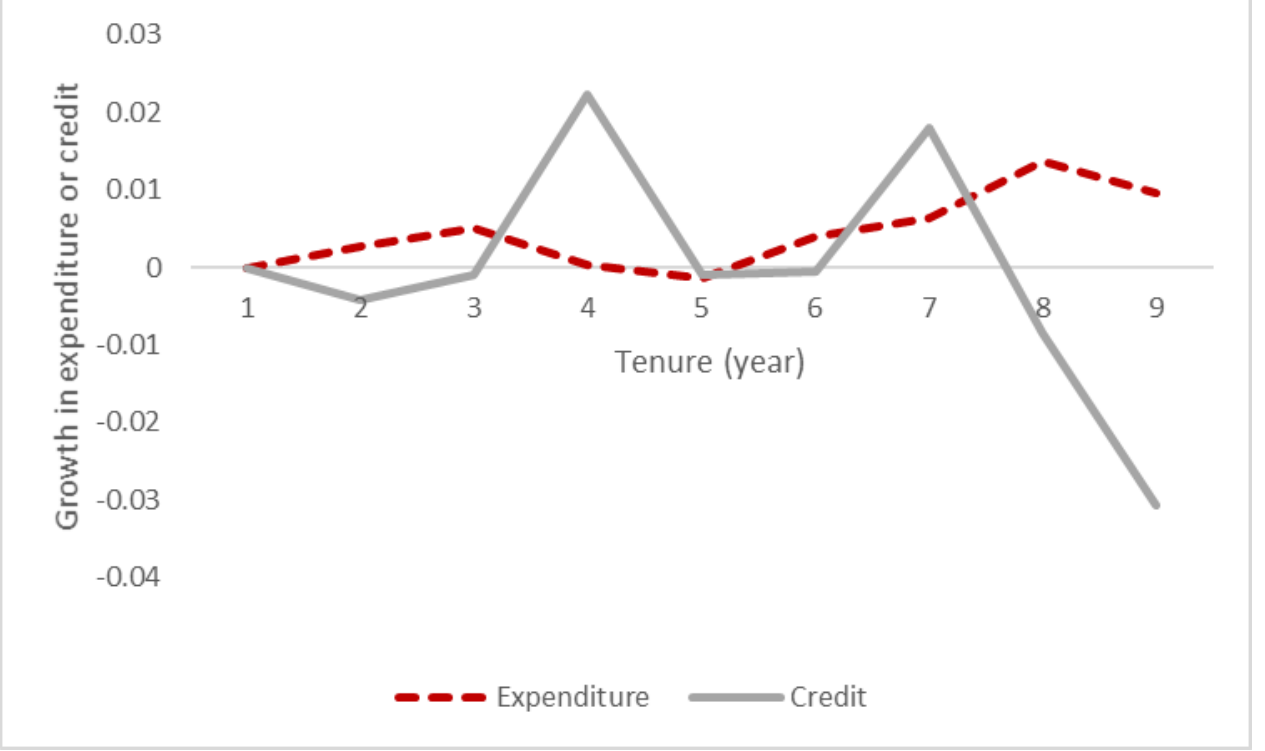

Notes: The figure plots credit (or expenditure) growth over the tenure of the provincial secretary, after controlling for province and year fixed effects. Credit (or expenditure) growth is measured by two-year change in real credit (expenditure) relative to two-year lagged GDP. Year 1 is normalized to zero. 
Figure 4. Sensitivity to other provinces' stimulus policies over the tenure of provincial secretaries

Panel A. Credit growth.

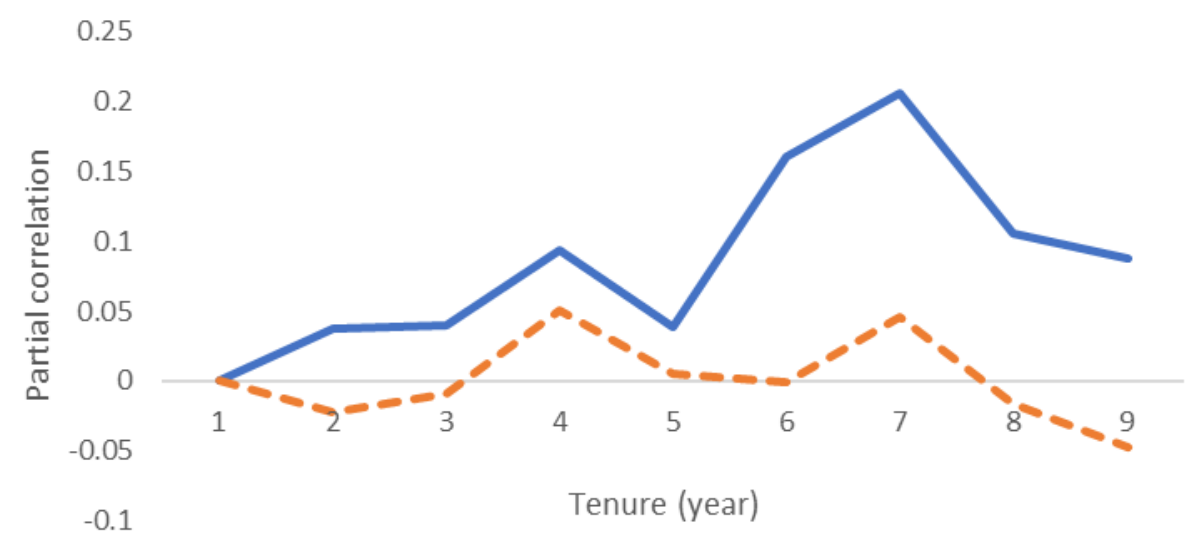

Sensitivity of credit to peer credit

- Sensitivity of credit to peer expenditure

Panel B. Expenditure growth

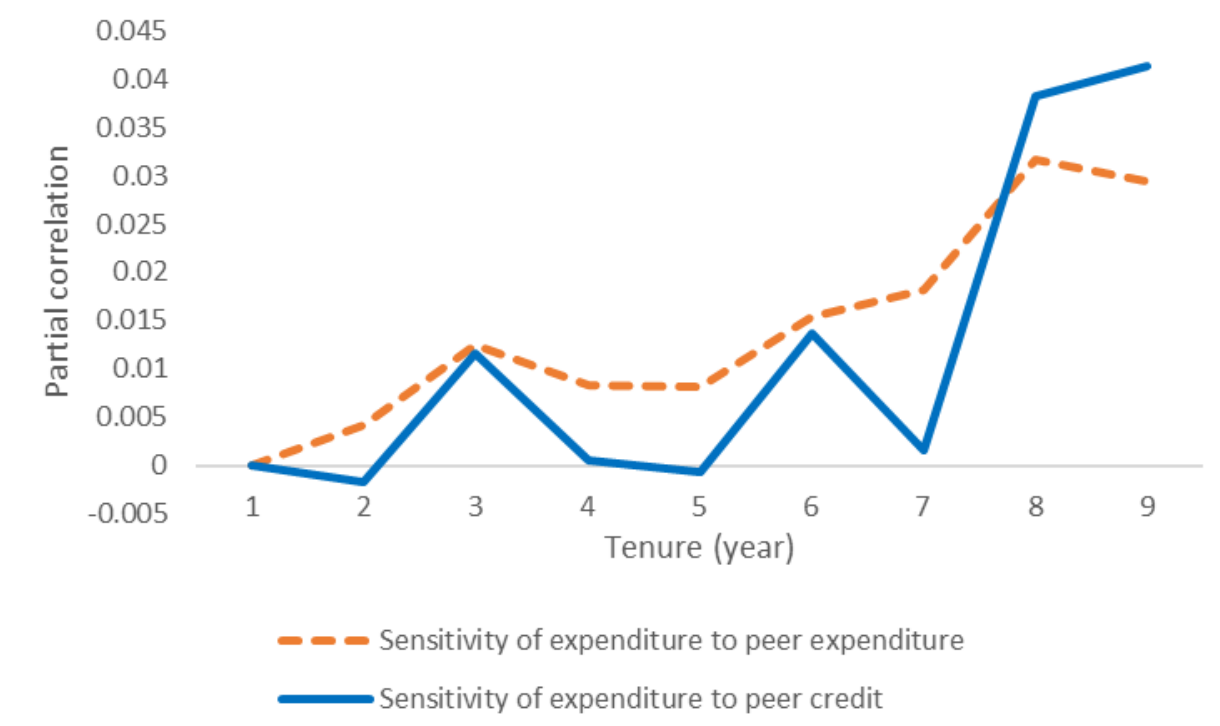

Notes: Panel A plots the correlation between a province's credit growth and credit (or expenditure) growth in other provinces over the tenure of the provincial party secretary, after controlling for province and year fixed effects. Panel B plots the correlation between a province's expenditure growth and expenditure (or credit) growth in other provinces over the tenure of the provincial party secretary. Credit (or expenditure) growth is measured by two-year change in real credit (expenditure) relative to two-year lagged GDP. Year 1 is normalized to zero. 
Table 1. Summary statistics

\begin{tabular}{lccccc}
\hline & $\mathrm{N}$ & Mean & St. Dev. & Min & Max \\
\hline $\begin{array}{l}\text { Nominal GDP (Bn RMB) } \\
\begin{array}{l}\text { Real growth rate (2-year, } \\
\text { relative to 2-year lag GDP) }\end{array}\end{array}$ & 465.00 & 1187.95 & 1252.82 & 13.92 & 7281.26 \\
$\quad$ & & & & \\
GDP & 386.00 & 0.27 & 0.09 & 0.06 & 0.45 \\
Credit & 387.00 & 0.32 & 0.16 & 0.05 & 0.85 \\
Expenditure & 386.00 & 0.07 & 0.05 & 0.02 & 0.34 \\
Construction & 387.00 & 0.02 & 0.01 & 0.00 & 0.08 \\
$\quad$ Manufacturing & 387.00 & 0.11 & 0.07 & -0.04 & 0.26 \\
$\quad$ Services ex financial sector & 385.00 & 0.10 & 0.03 & 0.05 & 0.19 \\
Secretary's tenure (years) & 465.00 & 3.28 & 2.24 & 1.00 & 15.00 \\
\hline
\end{tabular}


Table 2. Appointments of party secretaries and provincial economic conditions

\begin{tabular}{|c|c|c|c|c|c|c|c|c|c|c|c|c|}
\hline & \multicolumn{12}{|c|}{ Appointment of party secretary } \\
\hline & 1 & 2 & 3 & 4 & 5 & 6 & 7 & 8 & 9 & 10 & 11 & 12 \\
\hline \multirow{2}{*}{ Real GDP growth } & 0.729 & & & & & & & & & -5.515 & & \\
\hline & {$[1.476]$} & & & & & & & & & {$[10.593]$} & & \\
\hline \multirow[t]{2}{*}{ one-year lag } & & -0.670 & & & & & & & & & 1.324 & \\
\hline & & {$[1.436]$} & & & & & & & & & [13.357] & \\
\hline \multirow[t]{2}{*}{ two-year lag } & & & -0.144 & & & & & & & & & 2.958 \\
\hline & & & [1.924] & & & & & & & & & [7.203] \\
\hline \multirow{2}{*}{$\begin{array}{l}\text { Real GDP per capita } \\
\text { growth }\end{array}$} & & & & & & & & & & & & \\
\hline & & & & $\begin{array}{c}0.718 \\
{[1.447]}\end{array}$ & & & & & & $\begin{array}{c}7.354 \\
{[10.058]}\end{array}$ & & \\
\hline \multirow[t]{2}{*}{ one-year lag } & & & & & -0.471 & & & & & & -1.617 & \\
\hline & & & & & [1.339] & & & & & & {$[12.180]$} & \\
\hline \multirow[t]{2}{*}{ two-year lag } & & & & & & 0.095 & & & & & & 0.104 \\
\hline & & & & & & {$[1.758]$} & & & & & & [6.902] \\
\hline \multirow[t]{2}{*}{ Employment growth } & & & & & & & -2.478 & & & -2.603 & & \\
\hline & & & & & & & [3.676] & & & {$[3.495]$} & & \\
\hline \multirow[t]{2}{*}{ one-year lag } & & & & & & & & -3.309 & & & -3.610 & \\
\hline & & & & & & & & {$[3.803]$} & & & {$[4.653]$} & \\
\hline \multirow[t]{2}{*}{ two-year lag } & & & & & & & & & 4.871 & & & 4.068 \\
\hline & & & & & & & & & {$[4.540]$} & & & [2.892] \\
\hline Observations & 326 & 303 & 272 & 326 & 303 & 272 & 167 & 173 & 170 & 160 & 167 & 157 \\
\hline Province FE & Yes & Yes & Yes & Yes & Yes & Yes & Yes & Yes & Yes & Yes & Yes & Yes \\
\hline Year FE & Yes & Yes & Yes & Yes & Yes & Yes & Yes & Yes & Yes & Yes & Yes & Yes \\
\hline
\end{tabular}

Note: this table shows coefficients of a probit model where the independent variable is an indicator variable that takes a value of one if a new secretary is appointed. The dependent variables are two-year growth in real GDP, real GDP per capita and employment. All specifications include province and year fixed effects. All variables are winsorized at the 2 and 98 percent. All standard errors are clustered at the province level and reported in brackets. 
Table 3. Full sample results

\begin{tabular}{lcccccc}
\hline & \multicolumn{7}{c}{ Real GDP } \\
\cline { 2 - 7 } & 1 & 2 & 3 & 4 & 5 & 6 \\
& OLS & IV & OLS & IV & OLS & IV \\
\hline Real Credit & $0.221^{* * *}$ & $0.283^{* * *}$ & & & $0.191^{* * *}$ & $0.202^{* * *}$ \\
& {$[0.035]$} & {$[0.039]$} & & & {$[0.033]$} & {$[0.040]$} \\
Real Expenditure & & & $1.009^{* * *}$ & $1.083^{* * *}$ & $0.795^{* * *}$ & $0.793^{* * *}$ \\
& & & {$[0.186]$} & {$[0.290]$} & {$[0.175]$} & {$[0.292]$} \\
Observations & & & & & & \\
R-squared & 370 & 370 & 372 & 372 & 359 & 359 \\
Year and province FE & 0.770 & & 0.760 & & 0.803 & \\
Cragg-Donald Wald F & Yes & Yes & Yes & Yes & Yes & Yes \\
Kleibergen-Paap rk Wald F & & 105 & & 112.2 & & 51.65 \\
& & 27.10 & & 23.36 & & 14.75 \\
\hline
\end{tabular}

Note: this table shows results of OLS and IV regressions on credit and fiscal multipliers. The independent variable is two-year growth in real GDP, and the dependent variables are two-year growth in real credit and expenditure relative to two-year lagged GDP. All specifications include province and year fixed effects. All variables are winsorized at the 2 and 98 percent. All standard errors are clustered at the province level and reported in brackets. ${ }^{*}, * *$, and ${ }^{* * *}$ represent statistical significance at the 1 percent, 5 percent, and 10 percent, respectively. 
Table 4. Early and late subsamples results

\begin{tabular}{lcccc}
\hline & \multicolumn{2}{c}{ Real GDP } & \multicolumn{2}{c}{$2010-2015$} \\
\cline { 2 - 5 } & 1 & $2001-2008$ & 3 & 4 \\
& OLS & IV & OLS & IV \\
\hline Real Credit & $0.210^{* * *}$ & $0.172^{* * *}$ & 0.019 & 0.005 \\
& {$[0.062]$} & {$[0.064]$} & {$[0.168]$} & {$[0.095]$} \\
Real Expenditure & $0.696^{* * *}$ & $0.742^{* * *}$ & $0.878^{* *}$ & $1.395^{* * *}$ \\
& {$[0.196]$} & {$[0.277]$} & {$[0.320]$} & {$[0.272]$} \\
Observations & & & & \\
R-squared & 166 & 165 & 110 & 110 \\
Year and province FE & 0.723 & & 0.891 & \\
Cragg-Donald Wald F & Yes & Yes & Yes & Yes \\
Kleibergen-Paap rk Wald F & & 22.67 & & 15.68 \\
\hline
\end{tabular}

Note: This table shows results of OLS and IV regressions on credit and fiscal multipliers. The independent variable is two-year growth in real GDP, and the dependent variables are two-year growth in real credit and expenditure relative to two-year lagged GDP. All specifications include province and year fixed effects. All variables are winsorized at the 2 and 98 percent. All standard errors are clustered at the province level and reported in brackets. *, **, and $* * *$ represent statistical significance at the 1 percent, 5 percent, and 10 percent, respectively. 
Table 5. Weighted results

\begin{tabular}{lcccccc}
\hline & \multicolumn{2}{c}{ Full Sample } & \multicolumn{2}{c}{$2001-2008$} & \multicolumn{2}{c}{$2010-2015$} \\
\cline { 2 - 7 } & 1 & 2 & 3 & 4 & 5 & 6 \\
& OLS & IV & OLS & IV & OLS & IV \\
\hline Real Credit & $0.185^{* * *}$ & $0.180^{* * *}$ & $0.226^{* * *}$ & $0.178^{* *}$ & -0.023 & -0.057 \\
& {$[0.033]$} & {$[0.036]$} & {$[0.072]$} & {$[0.088]$} & {$[0.128]$} & {$[0.104]$} \\
Real Expenditure & $1.050^{* * *}$ & $0.760^{* *}$ & $0.798^{* *}$ & $0.844^{* *}$ & $1.458^{* * *}$ & $1.649^{* * *}$ \\
& {$[0.269]$} & {$[0.301]$} & {$[0.357]$} & {$[0.361]$} & {$[0.252]$} & {$[0.203]$} \\
& & & & & & \\
Observations & 359 & 359 & 166 & 165 & 110 & 110 \\
R-squared & 0.866 & 31 & 0.728 & 30 & 0.881 & 30 \\
Year and province FE & Yes & Yes & Yes & Yes & Yes & Yes \\
Cragg-Donald Wald F & & 97.22 & & 40.91 & & 37.34 \\
Kleibergen-Paap rk Wald F & & 24.92 & & 15.56 & & 8.120 \\
\hline
\end{tabular}

Note: This table shows results of OLS and IV regressions on credit and fiscal multipliers. The independent variable is two-year growth in real GDP, and the dependent variables are two-year growth in real credit and expenditure relative to two-year lagged GDP. All specifications include province and year fixed effects. All variables are winsorized at the 2 and 98 percent. All standard errors are clustered at the province level and reported in brackets. *,**, and $* * *$ represent statistical significance at the 1 percent, 5 percent, and 10 percent, respectively. 
Table 6. Sectoral multipliers

Panel A: Sectoral contributions, entire sample: 2001-2015

\begin{tabular}{|c|c|c|c|c|c|c|}
\hline & \multicolumn{2}{|c|}{ Construction } & \multicolumn{2}{|c|}{ Manufacturing } & \multicolumn{2}{|c|}{ Services ex financial } \\
\hline & 1 & 2 & 3 & 4 & 5 & 6 \\
\hline & OLS & IV & OLS & IV & OLS & IV \\
\hline \multirow[t]{2}{*}{ Real Credit } & $0.021 * * *$ & $0.015^{* *}$ & $0.083^{* *}$ & $0.109 * *$ & $0.062 * * *$ & $0.046^{* *}$ \\
\hline & {$[0.006]$} & {$[0.007]$} & {$[0.033]$} & {$[0.044]$} & {$[0.018]$} & {$[0.022]$} \\
\hline \multirow[t]{2}{*}{ Real Expenditure } & $0.084 * *$ & $0.055^{*}$ & $0.438 * * *$ & $0.606^{* * *}$ & $0.212 *$ & 0.138 \\
\hline & {$[0.039]$} & {$[0.033]$} & {$[0.135]$} & {$[0.220]$} & {$[0.109]$} & {$[0.099]$} \\
\hline Observations & 364 & 364 & 360 & 360 & 358 & 358 \\
\hline R-squared & 0.689 & & 0.767 & & 0.517 & \\
\hline Year and province FE & Yes & Yes & Yes & Yes & Yes & Yes \\
\hline Cragg-Donal Wald F & & 42.29 & & 42.48 & & 42.68 \\
\hline Kleibergen-Paap rk Wald F & & 14.67 & & 13.88 & & 12.69 \\
\hline
\end{tabular}

Panel B. Sectoral contributions, the post-crisis period, 2010-2015

\begin{tabular}{|c|c|c|c|c|c|c|}
\hline & \multicolumn{2}{|c|}{ Construction } & \multicolumn{2}{|c|}{ Manufacturing } & \multicolumn{2}{|c|}{ Services ex financial } \\
\hline & 1 & 2 & 3 & 4 & 5 & 6 \\
\hline & OLS & IV & OLS & IV & OLS & IV \\
\hline \multirow[t]{2}{*}{ Real Credit } & 0.009 & 0.003 & 0.079 & 0.070 & -0.067 & $-0.098 * *$ \\
\hline & {$[0.011]$} & {$[0.011]$} & {$[0.127]$} & {$[0.094]$} & {$[0.050]$} & {$[0.041]$} \\
\hline \multirow[t]{2}{*}{ Real Expenditure } & 0.032 & $0.073 * *$ & 0.361 & $0.678 * * *$ & 0.133 & $0.219 * *$ \\
\hline & {$[0.032]$} & {$[0.028]$} & {$[0.259]$} & {$[0.238]$} & {$[0.139]$} & {$[0.090]$} \\
\hline Observations & 364 & 364 & 360 & 360 & 358 & 358 \\
\hline R-squared & 0.689 & & 0.767 & & 0.517 & \\
\hline Year and province FE & Yes & Yes & Yes & Yes & Yes & Yes \\
\hline Cragg-Donald Wald F & & 13.45 & & 13.08 & & 11.99 \\
\hline Kleibergen-Paap rk Wald F & & 14.67 & & 13.88 & & 12.69 \\
\hline
\end{tabular}


Table 6. Sectoral multipliers (cont')

Panel C. Sectoral multipliers

\begin{tabular}{|c|c|c|c|c|c|c|}
\hline & \multicolumn{3}{|c|}{$\begin{array}{l}2001- \\
2015\end{array}$} & \multicolumn{3}{|c|}{$\begin{array}{l}2010- \\
2015\end{array}$} \\
\hline & $\begin{array}{l}\text { Cons- } \\
\text { truction }\end{array}$ & $\begin{array}{c}\text { Manu- } \\
\text { facturing }\end{array}$ & $\begin{array}{l}\text { Services } \\
\text { ex } \\
\text { financial }\end{array}$ & $\begin{array}{l}\text { Cons- } \\
\text { truction }\end{array}$ & $\begin{array}{l}\text { Manu- } \\
\text { facturing }\end{array}$ & $\begin{array}{l}\text { Services } \\
\quad \text { ex } \\
\text { financial }\end{array}$ \\
\hline & 1 & 2 & 3 & 4 & 5 & 6 \\
\hline Real Credit & & & & & & \\
\hline $\begin{array}{l}\text { Sectoral multiplier (i.e. } \\
\text { contribution to overall output } \\
\text { multiplier) }\end{array}$ & 0.015 & 0.11 & 0.046 & 0.003 & 0.07 & -0.098 \\
\hline divided by sectoral share in GDP & 0.075 & 0.39 & 0.37 & 0.078 & 0.39 & 0.37 \\
\hline obtains effect on industry growth & 0.20 & 0.28 & 0.12 & 0.04 & 0.18 & -0.27 \\
\hline $\begin{array}{l}\text { Real Expenditure } \\
\text { Sectoral multiplier (i.e. } \\
\text { contribution to overall output } \\
\text { multiplier) }\end{array}$ & 0.055 & 0.606 & 0.138 & 0.073 & 0.678 & 0.219 \\
\hline divided by sectoral share in GDP & 0.075 & 0.39 & 0.37 & 0.078 & 0.39 & 0.37 \\
\hline obtains effect on industry growth & 0.73 & 1.57 & 0.37 & 0.94 & 1.73 & 0.59 \\
\hline
\end{tabular}

Note: Panel A and B show results of OLS and IV regressions on sectoral multipliers. The independent variable is two-year growth in real sectoral output relative to GDP, and the dependent variables are two-year growth in real credit and expenditure relative to two-year lagged GDP. All specifications include province and year fixed effects. All variables are winsorized at the 2 and 98 percent. Panel $\mathrm{C}$ infers the effects of credit and expenditure from on sectoral growth from sectoral multipliers. All standard errors are clustered at the province level and reported in brackets. ${ }^{*}, * *$, and $* * *$ represent statistical significance at the 1 percent, 5 percent, and 10 percent, respectively. 


\section{REFERENCES}

Auerbach, Alan J., and Yuriy Gorodnichenko, 2012. "Fiscal multipliers in recession and expansion," in Fiscal Policy after the Financial crisis. University of Chicago Press.

Baum, Ms Anja, Mr Marcos Poplawski-Ribeiro, and Anke Weber, 2012. "Fiscal Multipliers and the State of the Economy," IMF Working Paper 12-286.

Bernanke, Ben S., and Mark Gertler, 1995. "Inside the Black Box: The Credit Channel of Monetary Policy Transmission," Journal of Economic Perspectives 9(4): 27-48.

Bernanke, Ben S., and Mark Gertler, 1989. "Agency costs, net worth, and business fluctuations," American Economic Review 87(5): 14-31.

Blanchard, Olivier J., and Daniel Leigh, 2013. "Growth forecast errors and fiscal multipliers," American Economic Review 103(3): 117-120.

Borio, Claudio, Enisse Kharroubi, Christian Upper, and Fabrizio Zampolli, 2016. "Labour Reallocation and Productivity Dynamics: Financial Causes, Real Consequences,” BIS Working Paper 534.

Bound, John, David A. Jaeger, and Regina M. Baker, 1995. "Problems with Instrumental Variables Estimation When the Correlation between the Instruments and the Endogenous Explanatory Variable Is Weak." Journal of American Statistical Association 90 (430): 44350 .

Chen, Ye, Hongbin Li, and Li-An Zhou, 2005. "Relative Performance Evaluation and the Turnover of Provincial Leaders in China," Economics Letters 88: 421-425.

Cong, Lin William, Haoyu Gao, Jacopo Ponticelli, and Xiaoguang Yang, 2017. "Credit Allocation under Economic Stimulus: Evidence from China," Chicago Booth Research Paper No. 17-19.

Dell'Ariccia, Giovanni, Deniz Igan, Luc Laeven, and Hui Tong, 2016. "Credit booms and Macrofinancial Stability," Economic Policy 31(86): 299-355.

Dittmer, Lowell, and Yu-Shan Wu, 1995. "The Modernization of Factionalism in Chinese Politics," World Politics 47(4): 467-494.

Gilchrist, Simon, and Egon Zakrajšek, 2012. "Credit Spreads and Business Cycle Fluctuations," American Economic Review 102(4): 1692-1720.

Guo, Gang, 2009. “China’s Local Political Budget Cycles," American Journal of Political Science 53(3): 621-632. 
He, Dong, Zhiwei Zhang, and Wenlang Zhang, 2009. "How Large Will Be the Effect of China's Fiscal Stimulus Package on Output and Employment?" Pacific Economic Review 14(5): 730-744.

IMF [International Monetary Fund], 2017, Staff Report for the 2017 Article IV Consultation with the People's Republic of China.

Jin, Hejui, Yingyi Qian, and Barry R. Weingast, 2005. "Regional Decentralization and Fiscal Incentives: Federalism, Chinese Style,” Journal of Public Economics 89: 1719-1742.

Kiyotaki, Nobuhiro, and John Moore, 1997. "Credit Cycles.” Journal of Political Economy 105(2): 211-248.

Li, Cheng, 2004. "Political Localism versus Institutional Restraints: Elite Recruitment in the Jiang Era," in B. J. Naughton \& D. L. Yang (Eds), Holding China Together. Cambridge University Press.

Li, Hongbin, and Li-An Zhou, 2005. "Political Turnover and Economic Performance: the Incentive Role of Personnel Control in China," Journal of Public Economics 89: 1743-1762.

Li, Qing, Xiu Wen and Yuzhe Zhang, 2008. "China Ramps Up Financial Sector Stimuli," Caijing Magazine, http:// english.caijing.com.cn/2008-12-09/110036510.html, accessed 15 August 2017.

Li, Yinan, 2011. "China's Political Business Cycles," Working paper. Accessed August 14, 2017, from http://www.chinasummerinstitute.org/wp-content/uploads/Chinas-PoliticalBusiness-Cycle.pdf.

Luo, Renfu, Linxiu Zhang, Jikun Huang, and Scott Rozelle, 2010. "Village Elections, Public Goods Investments and Pork Barrel Politics, Chinese-Style," Journal of Development Studies 46: 662-684.

O’Brien, Kevin J., and Lianjiang Li, 1999. "Selective Policy Implementation in Rural China," Comparative Politics 31(2): 167-186.

Nakamura, Emi, and Jon Steinsson, 2014. "Fiscal Stimulus in a Monetary Union: Evidence from US Regions," American Economic Review 104(3): 753-792.

Ru, Hong, 2017. "Government Credit, a Double-Edged Sword: Evidence from the China Development Bank", Journal of Finance, forthcoming.

Shen, Chunli, Jing Jin, Heng-fu Zou, 2012. "Fiscal Decentralization in China: History, Impact, Challenges and Next Steps," Annals of Economics and Finance 13(1): 1-51.

Song, Zheng, Kjetil Storesletten, and Fabrizio Zilibotti, 2011. "Growing Like China," American Economic Review 101(1): 196-233. 
Spilimbergo, Antonio, Steven Symansky, and Martin Schindler, 2009. Fiscal multipliers. IMF Staff Position Note 2009/11.

Stock, James H. and Motohiro Yogo, "Testing for Weak Instruments in Linear IV Regression," in James H. Stock and Donald W. K. Andrews, eds., Identification and Inference for Econometric Models: Essays in Honor of Thomas J Rothenberg, New York: Cambridge University Press, 2005.

Tao, Yi-Feng, 2006. "The Evolution of 'Political Business Cycle' in Post-Mao China," Issues and Studies 42(1): 163-194.

Tsai, Pi-Han, 2016. "Fiscal Incentives and Political Budget Cycles in China," International Tax and Public Finance 23: 1030-1073.

Wedeman, Andrew, 1999. "Agency and Fiscal Dependence in Central-Provincial Relations in China," Journal of Contemporary China 8(20): 103-122.

Wong, Christine, 2011. "The Fiscal Stimulus Programme and Public Governance Issues in China," OECD Journal of Budgeting 11/3. 